\title{
A Web Survey on Learning Environments and Staff in Swedish Leisure-Time Centres as a Starting Point for a Nordic Research Network and International Cooperation
}

\author{
Ann-Katrin Perselli, Gunnar Augustsson \& Lena Boström
}

\section{Leisure-Time Centres in Sweden}

The Leisure-Time Centres (LTCs) are well established in the Swedish community, with their roots in the work cottages of the late 1800 s, where children learned handicrafts as a preventive measure, as they often had to support themselves on their own. In the early 1900s, work cottages became more caring and after-school centres were established (Rohlin, 2012). These after-school centres developed during the 1960s into LTCs. The after-school operations at LTCs are still today voluntary and are aimed at younger school children (6-12 years old). In Sweden 444,400 children attend LTCs in the school year 2014-2015 (Skolverket [National Agency for Education], 2015a, 2015b).

But in spite of the large number of children attending them, it is not uncommon for LTCs to struggle with both limited resources and authorities who do not understand how LTCs operate. The Swedish Schools Inspectorate (Skolinspektionen, 2010, 2012; see also Lorentzi, 2012) has sharply criticized how LTCs fulfil their mission. The Schools Inspectorate stated that LTCs in Sweden have, among other things, a tendency to emphasize the care of the children at the expense of their learning, on account of limited resources. Further, the Schools Inspectorate pointed out that LTCs do not adequately follow up and analyse their operations to the extent necessary to develop their operations and make them better correspond to the curriculum goals.

According to the Schools Inspectorate (Skolinspektionen, 2012), the municipal authorities responsible for schools often lack insight into the importance of LTCs' educational role for children who would otherwise be at risk of alienation or other problems. Without this understanding, the responsible authorities prioritize conventional schools and formal education ahead of LTCs. Even concerning overhaul and 
control of the quality of the LTCs, with the aim to improve their quality, several municipalities made relatively little progress (Skolinspektionen, 2012).

It is hence remarkable that LTCs are such a relatively small research field in comparison with the research on compulsory and upper secondary schools, though over the last few years the research on LTCs and leisure-time teachers (LTTs) has gotten an impetus (see also Klerfelt \& Haglund, 2014). Therefore, it is important to do research on LTCs and their operations, both to understand and to spur their development.

\section{Leisure-Time Centres in the Nordic Countries}

Searches in the database ERIC show that LTCs as a research field in the Nordic countries are relatively new. The number of scientific articles from each Nordic country is relatively low, and they have mainly been produced since 2010 .

Of the Nordic countries, it is probably Denmark's LTC system that is closest to Sweden's (described above). In Denmark, children can attend an LTC or leisure club in a similar way as children do in Sweden. It is teacher trained staff who operate the Danish facilities. In Norway, the authority is responsible for the LTC operations. There are LTCs for schoolchildren in grades 1 to 4, but the staff do not need to have any teacher training to work in the LTCs (Andersson, 2013). The Norwegian LTC operations focus on childcare and providing meaningful leisure time (Kunnskapsdepartementet [Ministry of Education and Research], 2014). In Finland, like Norway, there are LTCs for children up to grade 4. Even Finland does not require the staff to be teacher trained, but in contrast to Norway, associations, churches, and municipalities run LTCs, which they do on a voluntary basis (Andersson, 2013). LTCs are a relatively new phenomenon in Iceland (Pálsdóttir, 2012). During the 1970s, Iceland started the first LTC on a voluntary basis. Icelandic LTCs are run by the municipality, but they can also be run by other authorities, such as the Sports and Recreation Council. Icelandic LTCs do not require any teacher training of those who wish to work at one (Pálsdóttir, 2012).

\section{Initiation of a Survey on the Learning Environment in the LTCS and the Competencies and Leadership of the Staff}

Our interest in research into LTCs started in 2011 when we discovered that there was a shortage of contemporary overall information and knowledge about LTCs. At that time, important questions about the LTC model - including the appearance of the LTC learning environments, how LTCs support children, and how LTTs handle and use leadership in their work - were quite unexplored.

When the current Swedish teacher-training programmes started in 2011 they were supposed to be based on contemporary research. But compared with the other 
teacher-training programmes, there was very little contemporary research on LTCs and the new curriculum to establish a teacher-training programme for LTTs (the so called Teacher-Training Programme with Aim Towards Leisure-Time Centre). The field of knowledge concerning the new curriculum and LTC operations was undeveloped and new research was greatly needed. The link to contemporary research is essential if the new teacher training is going to rest on a solid scientific basis, which was the demand from the government to the universities.

To get a current overview in the present situation for the Swedish LTCs, a Web survey was constructed using the Netigate software (Netigate, 2014). In early 2013 the Web survey was sent to all employees at LTCs in Sweden (about 11,109 persons). It was distributed by the Teacher's Federation via a link in an e-mail. Responses were received from 4,043 persons ( $36 \%$ of those contacted). Altogether, the respondents represented 289 of Sweden's 290 municipalities. The questionnaire consisted of 21 questions on two main topics: the learning environment in the LTCs and the competencies and leadership of the staff. Some of the questions could be answered only by set responses, while others were open-ended questions allowing written statements.

Up to now the analysis of the web survey already resulted in relevant papers (Boström, Hörnell, \& Frykland, 2015; Boström \& Augustsson, 2016; Augustsson, 2016) and further papers are in preparation (e.g. Perselli, Hörnell, \& Frykland, 2016).

\section{Starting an International Research Network}

In order to develop the research further, a request was submitted to the Faculty Board of Mid Sweden University for funds to start an international research network. The purpose of this application was to obtain resources to investigate the possibility of pursuing cooperative research into LTCs and LTC pedagogy among Denmark, Iceland, Norway, and Sweden. We visited Iceland and Denmark to establish contacts for further research, and these contacts in turn have visited us to plan further cooperative research. The starting point of the discussions was the above-mentioned web survey and the knowledge that the data might provide.

There is much we can learn from each other's experiences with and knowledge of LTT teacher training and work on LTCs in the Nordic region. Today, our research network consists of a multidisciplinary team of eight persons: from Sweden, Lena Boström, Gunnar Augustsson, Assar Hörnell, and Marie Frykland (Mid Sweden University) and Ann-Katrin Perselli (Linnaeus University); from Denmark, Frans Ørestad Andersen (Aarhus University); and from Iceland, Kolbrún Porbjörg Pálsdóttir and Steingerður Kristjánsdóttir (University of Iceland). There are also plans to seek participants in Finland. Presently the research network involves the following disciplines: education, leisure pedagogics, library and information science, political science, psychology, and sociology. 


\section{Further Research and Next Steps}

The research network aims to understand and explain how LTTs perceive the policy documents and implement them by giving children meaningful leisure time and space for participation and stimulating their learning and development (cp. Skolverket [National Agency for Education], 2011). In our view LTTs are under conflicting pressures regarding the policy documents and implementation of the content of the documents. Illuminating this situation can enable new knowledge of how LTTs interpret their mission, practice, and motives. Based on this assumption, we intend to study the organizational strategies that are used to interpret and transform the government-stated mission and values of LTC policy documents. Other issues of interest are the factors that set the frames for LTTs' work and the physical and intellectual tools used to manage them in the practical work.

Further research should give emphasis on comparative studies. For example, the new Swedish curriculum's first two chapters are intended for LTCs. However, these chapters are written from a school perspective, which entails an orientation of LTC operations for more formal education. The Swedish Schools Inspectorate (Skolinspektionen, 2010) emphasizes that legislators leave a complex challenge of interpretation and implementation to these teachers as they try to interpret and transform their mission. Therefore it is important to explore how values and mission in the policy documents are interpreted and put into practice in LTCs from a Nordic perspective.

An important area for further research would be to deepen the analysis of the empirical material with a quantitative analysis. There are also more data to get out of the Swedish Web survey.

Perselli has started to analyse the Web survey data with the aim of studying how information technology and information and communication technology are used in LTCs. When an LTC is a part of the school, the headmaster ought to provide the LTCs with modern and usable equipment. To follow up this subject Perselli will conduct interviews to widen the data and to compare with the Web survey data.

Another research area will be to involve the children who attend LTCs and hear their opinions concerning the premises within schools or at independent centres and how it impacts their desire for learning and development. This research subject would be very interesting in a comparative study between the Nordic countries.

International exchanges of ideas and results, which we have described in this article, becomes important if it can provide a basis for the development of the quality of LTCs' operations, and thereby support children's learning and development. 


\section{References}

Andersson, B. (2013). Nya fritidspedagoger - i spänningsfältet mellan tradition och nya styrformer [New leisure-time pedagogues - in tension between tradition and new forms of governance]. (Doctoral thesis, Institutionen för tillämpad utbildningsvetenskap, Umeå universitet, Umeå, Sweden).

Augustsson, G. (2016). The complexities of leisure-time teachers'leadership in the leisure-time centre learning environment. Manuscript in preparation.

Boström, L., \& Augustsson, G. (2016 ). Learning environments in Swedish Leisure-time Centres. (In)equality, 'Schooling', and Lack of Idependence. International Journal for Research on Extended Education, 4(1). In press.

Boström, L., Hörnell, A., \& Frykland, M. (2015). Learning environments at leisure-time centres in Sweden: A comprehensive survey of staff perceptions. International Journal for Research on Extended Education, 3(1), 5-18.

Klerfelt, A., \& Haglund, B. (2014). Presentation of research on school-age educare in Sweden. International Journal for Research on Extended Education, 2(1), 45-62.

Kunnskapsdepartementet [Ministry of Education and Research]. (2014). Skolefritidsordningen (SFO). Retrieved from https://www.regjeringen.no/no/tema/utdanning/grunnopplaring/artikler/skolefritidsordningen-sfo/id434946.

Lorentzi, U. (2012). Har någon sett Matilda? Vad fritidshemmen är och vad de skulle kunna vara [Has anyone seen Matilda? What leisure-time centres are and what they could be]. Stockholm: Kommunal.

Netigate. (2014). Webenkät [Web survey]. Retrieved from https://www.netigate.se.

Pálsdóttir, K. P. (2012). Care, learning and leisure: The organisational identity of after-school centres for six-to nine-year old children in Reykjavik (Doctoral thesis, School of Education, University of Iceland, Reykjavík, Iceland). Retrieved from: http://skemman.is/stream/get/1946/16754/38970/1/phd_thesis_palsdottir. pdf.

Perselli, A.-K., Hörnell, A., \& Frykland, M. (2016). Leisure-time centre's complement of school: Leisure-time teachers' understanding of the mission. Manuscript in preparation.

Rohlin, M. (2012). Fritidshemmets historiska dilemman: En nutidshistoria om konstruktionen av fritidshemmet i samordning med skolan [Leisure-time centres' historical dilemmas: A contemporary history of the construction of the leisure-time centre in coordination with the school]. Stockholm: University of Stockholm.

Skolinspektionen [Swedish Schools Inspectorate]. (2010). Kvalitet $i$ fritidshem [Quality in leisure-time centre]. Stockholm: Skolinspektionen.

Skolinspektionen [Swedish Schools Inspectorate]. (2012). En skola med tilltro lyfter alla elever. Skolinspektionens erfarenheter och resultat från tillsyn och kvalitetsgranskning 2011 [A school with confidence lifts all students: The Swedish Schools Inspectorate experiences and results of supervision and check of quality 2011]. Stockholm: Skolinspektionen. 
Skolverket [National Agency for Education]. (2011). Curriculum for the compulsory school system, the pre-school class and the leisure-time centre 2011. Stockholm: Skolverket.

Skolverket [National Agency for Education]. (2015a). Statistik om fritidshem [Statistics for leisure-time centres]. Retrieved from http://www.skolverket.se/ statistik-och-utvardering/statistik-i-tabeller/fritidshem.

Skolverket [National Agency for Education]. (2015b). Statistik om gymnasieskolan [Statistics about secondary school]. Retrieved from http://www.skolverket.se/ statistik-och-utvardering/statistik-i-tabeller/gymnasieskola. 